\title{
Determinants of Customer Service Quality on Hotel Guest Satisfaction in the Samosir Tourism Area with a Structural Equation Modeling Approach
}

\author{
Yossie Rossanty ${ }^{1}$, Muhammad Dharma Tuah Putra Nasution ${ }^{2}$, Irawan ${ }^{3}$ \\ ${ }^{1,2,3}$ Faculty of Social Science, Universitas Pembangunan Panca Budi, Medan, Indonesia
}

\section{Abstract}

The purpose of this study is to test the determinants of service quality aspects of Reliability, Responsiveness, Assurance, Empathy and Tangibles on the satisfaction of hotel tourists in the Samosir area. This research test tool using the Structural Equation Modeling model. The results prove that the structural model Reliability to Costomer Satisfaction is significant, meaning that reliability has a significant effect on Costomer Satisfaction. Responsivenes structural model to Costomer Satisfaction is significant, meaning that responsiveness has a significant effect on Costomer Satisfaction. Structural model assurance for Costomer Satisfaction is significant, meaning that assurance has a significant effect on Costomer Satisfaction. The structural model of empathy for Costomer Satisfaction is significant, meaning that empathy has a significant effect on Costomer Satisfaction. Tangibless structural model to Costomer Satisfaction is insignificant, meaning that tangibless has no significant effect on Costomer Satisfaction. Structural model assurance for Costomer Satisfaction is significant, meaning that assurance has a significant effect on Costomer Satisfaction. The structural model of empathy for Costomer Satisfaction is significant, meaning that empathy has a significant effect on Costomer Satisfaction. Tangibless structural model to Costomer Satisfaction is insignificant, meaning that tangibless has no significant effect on Costomer Satisfaction. Structural model assurance for Costomer Satisfaction is significant, meaning that assurance has a significant effect on Costomer Satisfaction. The structural model of empathy for Costomer Satisfaction is significant, meaning that empathy has a significant effect on Costomer Satisfaction. Tangibless structural model to Costomer Satisfaction is insignificant, meaning that tangibless has no significant effect on Costomer Satisfaction.
Keywords

service quality (reliability, responsiveness, assurance, empathy and tangibless); satisfaction

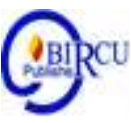

\section{Introduction}

Tourism is an industrial sector which is currently got a lot of attention from many countries in the world. The tourism sector is believed to have the ability to increase economic growth (Maciej Debski 2013). Moreover, the tourism sector is positively encouraged to be able to replace the oil and gas sector which has been the main capital in the country's foreign exchange earnings (Siswanto 2007). The advantage of the tourism sector lies in its ability to increase foreign exchange and to drive various other business sectors such as the home industry. Thus, developed countries and developing countries continue to develop and improve the quality of their country's tourism. (Amin et al, 2019). 
Tourism is one of the determinants of national economic growth because it can influence the growth of other sectors in the economy (Gokovali \& Bahar, 2006) and also grows very fast during this decade (Dogru \& Bulut, 2018; Wu et al., 2000). Sustainable tourism development can be completed by creating opportunities through networking and cooperation with service providers, where stakeholder engagement, the development of locally oriented codes of conduct, and local government participation are crucial factors for sustainable tourism success (Welford \& Ytterhus in Nurlina, 2020).

Tourist satisfaction is a very important factor and determines the success of a hotel industry because tourists are the motor / driving force of revenue generated by hotels. Tourist satisfaction is the feeling of pleasure or disappointment of someone who arises after comparing their perceptions / impressions of the performance (results) of a service and their expectations. The level of satisfaction is a function of the difference between perceived performance and expectations. If the performance is below expectations, tourists will be disappointed. Satisfied tourists will stay longer, less sensitive to price and give good comments about the Hospitality Industry.

Therefore, the Hospitality Industry must be able to meet the needs and desires of tourists so as to achieve tourist satisfaction and furthermore, tourist loyalty can be achieved in the future. This is because if it is not able to meet the needs and satisfaction of tourists, it will cause tourist dissatisfaction, which will cause tourist loyalty to a product to fade and switch to products or services provided by other competitors. One of the important factors that can influence the level of tourist satisfaction is the quality of the services provided.

Service is an activity or a series of activities that are invisible to the eye (cannot be felt) which occurs as a result of interactions between tourists and employees or other things caused by the Hospitality Industry providing services which are intended to solve tourist / tourist problems. Service quality can be measured through several dimensions that describe aspects of service. These dimensions are Reliability, Responsiveness, Assurance, Empathy and Tangibles.

Reliability namely the ability to provide services in accordance with the promises offered. Responsiveness is the response or the readiness of employees in helping tourists and providing fast and responsive service. Assurance is the knowledge, courtesy and ability of the Hospitality Industry Tourists to foster a sense of trust from tourists in the Hospitality Industry. Empathy is the individual attention that the Hospitality Industry gives to tourists. Such as the ease with which tourists contact the Hospitality Industry, the ability of employees to communicate with tourists, etc. Tangibles, namely the ability of a Hospitality Industry to show its existence to external parties.

Service quality and tourist satisfaction are closely related, good service quality provides an impetus for tourists to form strong ties with the Hospitality Industry. In the long term this kind of engagement allows the Hospitality Industry to understand carefully the expectations of its travelers and their needs. Thus the Hospitality Industry can increase tourist satisfaction where the Hospitality Industry maximizes the pleasant tourist experience and minimizes or eliminates unpleasant tourist experiences. In turn, tourist satisfaction can create tourist loyalty or loyalty to the Hospitality Industry which provides satisfactory quality. 


\subsection{Service Quality}

\section{Review of Literatures}

In essence, service quality is an activity that cannot be defined separately and is intangible, which fulfills needs and does not have to be tied to the sale of other products or services. Service can be said as a benefit and satisfaction activity that is offered for sale. This is because the purchase of a service often involves the attitudes and layouts that complement it.Before talking about service quality, first understand the definition of service itself.

Swastha (2005: 318) defines services, namely: "Intangible products that are bought and sold in the market through a mutually satisfying exchange transaction." Kotler in Fandy Tjiptono (2005: 6) defines service as: "Every action or action that can be offered by another party which is basically intangible (intangible) and does not result in ownership of something." Suryana (2007: 2) states that: "Tourist services are the provision of labor and other resources aimed at increasing the benefits received by tourists as a result of purchases made and from the process leading to the purchase."

\subsection{Factors Affecting Service Quality}

Quality has a close relationship with tourist satisfaction. Quality emphasizes the aspects of tourist satisfaction and income. Quality provides an incentive for tourists to forge strong ties with the Hospitality Industry. In the long term this kind of engagement allows the Hospitality Industry to understand carefully the expectations of tourists and their needs. There are several factors that affect service quality. According to Gronroos in Fandy Tjiptono (2002: 60) service quality is influenced by three components, namely:

1) Technical Quality (Technical Quality)

2) Functional Quality (Functional Quality)

3) Corporate Image (Overview of the Hospitality Industry)

\subsection{Service Quality Dimensions and Indicators}

In connection with the role of contact personal which is very important in determining service quality, every Hospitality Industry requires service excellence. According to Fandy Tjiptono (2002: 70) what is meant by service excellence is serving tourists satisfactorily, in general there are five dimensions in determining the quality of superior service, namely:

1). Reliability (accuracy)

2). Responsiveness (responsiveness)

3). Assurance (guarantee and security)

4).Empathy (attention)

5). Tangibles (physical condition)

\subsection{Tourist Satisfaction}

Tourists are the key word for the success of the Hospitality Industry. Such an important role has forced every Hospitality Industry to make efforts to formulate tips or strategies to attract them, so that they become buyers of their products Suharto (2009: 54) says "tourist satisfaction is a condition that describes the fulfillment, even the expectation of tourists for a product or service carried out by the producer". Supranto (2010: 233): "Satisfaction is the level of a person's feelings after comparing the performance / results he feels with his expectations." While Tjiptono (2001: 78) argues that: "Tourist satisfaction or dissatisfaction is the response of tourists to the evaluation of the mismatch or disconfirmation, which is felt between previous expectations (or other performance norms) and the actual performance of the product that is felt after its use". Zulian Yamit (2001: 78) states that: "Tourist satisfaction is an evaluation after comparing what is felt with expectations. 


\subsection{Factors Affecting Tourist Satisfaction}

Many factors influence tourist satisfaction in fulfilling tourists' desires and desires. In determining the level of tourist satisfaction, there are five main factors that must be considered by the Hospitality Industry (Rambat Lupiyoadi, 2001: 158), namely:

1) Product quality

2) Quality of service

3) Emotional

4) Price

5) Costs

The following is an explanation:

1) Product quality

Tourists will be satisfied when their evaluation results show that the products they use are of good quality.

2) Service quality

Tourists will feel satisfied if they get good service or what is expected (especially for the service industry).

3) Emotional

Tourists will feel proud and get the confidence that other people will be amazed by them when using products with certain brands that tend to have higher levels of satisfaction.

4) Price

Products that are of the same quality but set a relatively cheap price will provide higher value to tourists.

5) Cost

Tourists do not need to pay extra or do not need to waste time getting a product or tourists tend to be satisfied with the product or service.

Tourists do not need to pay extra or do not need to waste time getting a product or tourists tend to be satisfied with the product or service. Basically, tourists' satisfaction and dissatisfaction with the product will affect the subsequent behavior patterns. This is shown by tourists after the purchase process occurspost purchase action (Kotler, 2005: 59).

\subsection{Tourist Satisfaction Indicator}

Measuring tourist satisfaction can use attributes that contain how tourists rate a product or service from a tourist point of view.

Suharto (2009: 64) suggests several methods that can be used to measure tourist satisfaction, these methods include:

1) Complaints and suggestions system

2) Survey of tourist satisfaction

3) Traveler Panel

The following is an explanation:

1) Complaints and suggestions system

This system provides an opportunity for tourists to provide suggestions, complaints and other forms of dissatisfaction by providing a suggestion box. Every suggestion and complaint that comes in must be a concern for the Hospitality Industry, because suggestions and complaints are generally based on their experience and this is a form of their love for products / services.

2) Survey of tourist satisfaction

Tourist surveys are a commonly used method of measuring tourist satisfaction, for example, through postal mail, telephone, or in-person interviews. 


\section{3) Panel traveler}

Industrial Hospitality invites customers who are loyal to their products and invite tourists who have stopped buying or have moved to become other Hospitality Industry tourists. From tourists after they will get information on the level of satisfaction they feel and tourists who have stopped buying, Industry Hospitality will get information about why this happened. If tourists stop (the customer loss rate) increases, this indicates the failure of the Hospitality Industry to satisfy tourists. Peters in Zulian Yamit (2001: 80-81) suggests that there are ten (10) keys to success in measuring tourist satisfaction, namely:

1) Frequency

2) Format

3) Contents

4) Content design

5) Involve everyone

6) Measure everyone's satisfaction

7) Combination of various sizes

8) Relationship with compensation and other rewards.

9) Symbolic use of size

10). other forms of measurement

\subsection{Concept and Hypothesis Framework}

Service quality has a close relationship with tourist satisfaction. The quality of service provides an impetus for tourists to forge a strong relationship with the Hospitality Industry. Service quality can be measured through several dimensions that describe aspects of service. These dimensions are Reliability (accuracy), Responsiveness (responsiveness), Assurance (guarantee or security), Empathy (attention) and Tangibles (physical condition).

Ariyanti, Haruman, Ridwansyah and Andre (2009) prove that service quality affects satisfaction. In line with the findings, Ariyani and Rosinta (2010) also prove that there is a significant and positive direct relationship between value and tourist loyalty. As a result of the dissatisfaction with the performance of the attributes of savings services that tourists feel, the tourist loyalty is reduced. Likewise, the research findings of Rustika Atmawati (2007) which prove that there is a strong and positive influence between the variables of service quality satisfaction.

Reability (accuracy) is the ability of the Hospitality Industry to provide services as promised accurately and reliably. The service is in accordance with the expectations of tourists which means punctuality, the same service for all tourists without errors, a sympathetic attitude, and with high accuracy so that high tourist satisfaction will be created for the accuracy of the services provided. The more accurate the services provided, the better the quality of the services provided so that it will have a positive impact on customer satisfaction.

H1: Reability has an effect on tourist satisfaction in using hotel services in the Samosir area

Responsiveness, namely a willingness to help and provide fast (responsive) and precise service to tourists, with clear information delivery. With the responsiveness and alertness of Industi Hospitality employees in providing services, it will have an impact on meeting high tourist satisfaction. The faster and more responsive the service provided shows the better the quality of service provided so that it will have a positive impact on customer satisfaction.

H1: Responsiveness affects tourist satisfaction in using hotel services in the Samosir area

Assurance (guarantee and security), namely the quality of service shown by the knowledge, courtesy, and ability of the Hospitality Industry Tourists to foster the trust of 
tourists in the Hospitality Industry. With good guarantee and security, tourists will feel satisfied with the services provided. The better and more guaranteed the service provided, the better the quality of service provided so that it will have a positive impact on customer satisfaction. This guarantee can be in the form of guarantees of cleanliness, health, safety and suitability of services.

H1: Assurance has an effect on tourist satisfaction in using hotel services in the Samosir area

Empathy (attention) is the quality of service that gives sincere and individual attention to tourists by trying to understand the tourists' desires. Employees who have good empathy for tourists will be able to build high satisfaction as well. The better the attention of the hotel manager in providing services, the better the quality of service provided so that it will have a positive impact on customer satisfaction.

H1: Empathy affects tourist satisfaction in using hotel services in the Samosir area

Tangibles(physical condition), namely the quality of service shown through the appearance and ability of the physical facilities and infrastructure of the Hospitality Industry and the condition of the surrounding environment is clear evidence of the services provided by the service provider. The better the physical condition of the Hospitality Industry, the tourists will feel satisfied with the services provided. Physical conditions can be seen from the physical form of the hotel, existing facilities, accommodation and so on which form services that can be felt directly.

H1: Tangibles affects tourist satisfaction in using hotel services in the Samosir area

Based on the description of the conceptual framework, it can be described the influence of service quality on tourist satisfaction which can be seen in the conceptual framework image below:

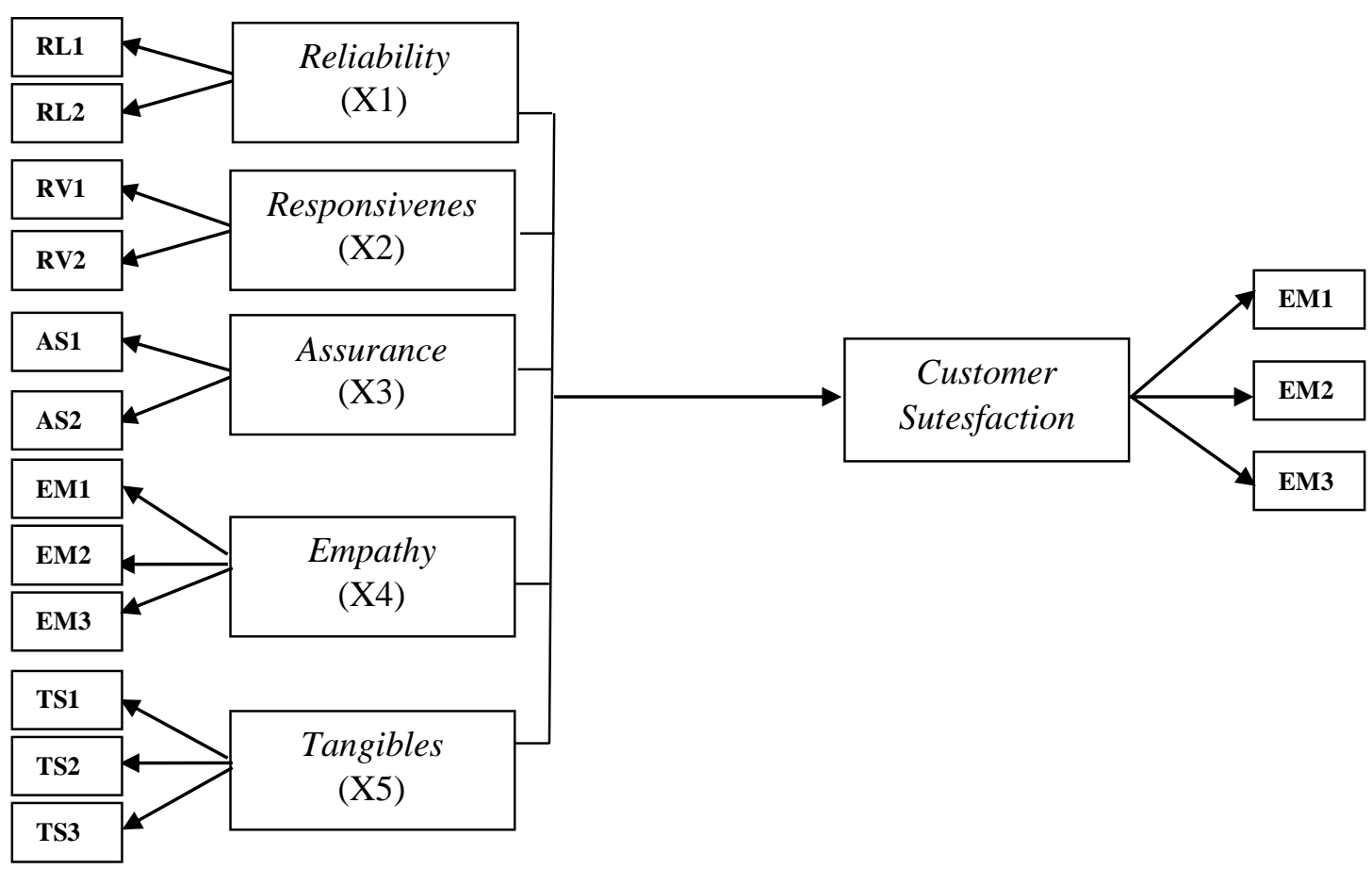

Figure 1. Conceptual Framework 


\section{Research Methods}

\subsection{Data and Estimates}

Retrieval of data through questionnaires to Tourists who visit and stay at the Samosir Area Hotel. The sampling technique used exidental sampling technique, namely the subjects taken were tourists who during the study period and sampling were encountered and according to the sample criteria so that 230 samples were obtained.The operationalization of exogenous and endogenous variables and their measurements are as follows:

Table 1. Operational Variables

\begin{tabular}{|c|c|c|c|}
\hline Variable & Operional Definition & Indicator & $\begin{array}{c}\text { Measure } \\
\text { Scale }\end{array}$ \\
\hline Reliability (X1) & $\begin{array}{l}\text { Reliability namely the ability } \\
\text { to provide services in } \\
\text { accordance with the promises } \\
\text { offered }\end{array}$ & $\begin{array}{l}\text { 1. Services in accordance with } \\
\text { the needs, abilities (skills) of } \\
\text { employees possessed. } \\
\text { 2. Accuracy of guest handling } \\
\text { or administration }\end{array}$ & Likert scale \\
\hline $\begin{array}{l}\text { Responsiveness } \\
\text { (X2) }\end{array}$ & $\begin{array}{l}\text { Responsiveness namely } \\
\text { employee response or } \\
\text { alertness in helping } \\
\text { customers and providing fast } \\
\text { and responsive service }\end{array}$ & $\begin{array}{l}\text { 1. The alacrity of employees in } \\
\text { serving customers. } \\
\text { 2. Willingness of employees to } \\
\text { assist customer difficulties } \\
\text { and respond to customer } \\
\text { requests }\end{array}$ & Likert scale \\
\hline Assurance (X3) & $\begin{array}{l}\text { Assurance namely } \\
\text { knowledge, courtesy, and the } \\
\text { ability of corporate tourists to } \\
\text { foster customer trust in the } \\
\text { company }\end{array}$ & $\begin{array}{l}\text { 1. Guaranteed company } \\
\text { reputation. } \\
\text { 2. Security in utilizing the } \\
\text { services offered }\end{array}$ & \\
\hline Empathy (X4) & $\begin{array}{l}\text { Empathy that is, the } \\
\text { individual attention the } \\
\text { company gives to customers }\end{array}$ & $\begin{array}{l}\text { 1. The ease with which } \\
\text { customers can contact the } \\
\text { company and the ease of } \\
\text { getting satisfying service. } \\
\text { 2. The ability of employees to } \\
\text { communicate with customers } \\
\text { as well as personal attention } \\
\text { to customers. } \\
\text { 3. Taking customer needs } \\
\text { seriously }\end{array}$ & \\
\hline Tangibles (X5) & $\begin{array}{l}\text { Tangibles namely the ability } \\
\text { of a company to show its } \\
\text { existence to external parties. } \\
\text { The appearance and ability of } \\
\text { the company's physical } \\
\text { facilities and infrastructure } \\
\text { and the condition of the } \\
\text { surrounding environment are } \\
\text { clear evidence of the services } \\
\text { provided by the service } \\
\text { providers }\end{array}$ & $\begin{array}{l}\text { 1. The comfort of the room and } \\
\text { the cleanliness of the } \\
\text { physical facilities of the } \\
\text { company room } \\
\text { 2. The layout of the room and } \\
\text { parking is neat and the } \\
\text { appearance of the employees } \\
\text { is neat } \\
\text { 3. The modernity (modernity) } \\
\text { of the physical facilities that } \\
\text { are owned }\end{array}$ & \\
\hline
\end{tabular}




\begin{tabular}{|c|c|c|c|}
\hline $\begin{array}{c}\text { Customer } \\
\text { Sutisfaction }(\mathrm{Y})\end{array}$ & $\begin{array}{l}\text { Feelings of happiness or } \\
\text { disappointment in someone } \\
\text { that comes after comparing } \\
\text { their perceptions } \\
\text { impressions of the } \\
\text { performance (or results) of a } \\
\text { product and their } \\
\text { expectations. }\end{array}$ & $\begin{array}{l}\text { 1. Convenience in obtaining } \\
\text { services } \\
\text { 2. Convenience in obtaining } \\
\text { facilities } \\
\text { 3. Fulfillment of consumer } \\
\text { expectations and the } \\
\text { conformity between price } \\
\text { and service received. }\end{array}$ & Likert scale \\
\hline
\end{tabular}

\subsection{Research Model}

For data analysis from this study, Structural Equation Modeling (SEM) was used.. SEM is a statistical modeling technique that is highly cross-sectional, linear and general in nature. Included in this SEM are factor analysis, path analysis and regression. Structural equation modeling (SEM) develops and has a function similar to multiple regression, however SEM has become a stronger analytical technique because it considers interaction modeling, nonlinearity, correlated independent variables, measurement error, interference errors. correlated error terms, several latent independent variables (multiple latent independents) where each is measured using multiple indicators, and one or two latent dependent variables which are also each measured by several indicators.

\section{Result and Discussion}

\subsection{Respondent Description}

Before discussing the statistical data, the researcher first describes the respondent's data that has been determined as the sample in this study. The objects sampled were 230 people consisting of hotel guests in the Samosir area.

\section{a. Characteristics of Respondents Based on Gender}

Characteristics Hotel guests in the Samosir area based on gender can be seen in the following explanation in Table 4.2:

Table 2. Respondents by Gender

\begin{tabular}{cccr}
\hline No. & Gender & Number of Respondents & Proportion (\%) \\
\hline 1 & Woman & 147 & 63.91 \\
\hline 2 & Men & 83 & 36.09 \\
\hline & total & $\mathbf{2 3 0}$ & $\mathbf{1 0 0}$ \\
\hline
\end{tabular}

Source: primary data processed, 2020

From Table 2, it can be seen that the respondents in this study based on female gender were 147 people or $63.91 \%$, while the number of male tourists was 83 people or $36.09 \%$. The data shows that the majority of hotel guests in the Samosir area are female. This shows that women dominate in visiting Samosir tours. 


\section{b. Characteristics of Respondents by Age}

Characteristics Hotel guests in the Samosir area by age can be seen in the following explanation in Table 3:

Table 3. Respondents by Age

\begin{tabular}{cccc}
\hline No. & Age & Total & Proportion $(\boldsymbol{\%})$ \\
\hline 1 & $25-30$ years & 35 & 15.22 \\
\hline 2 & $31-35$ Years & 41 & 17.83 \\
\hline 3 & $36-40$ Years & 50 & 21.74 \\
\hline 4 & $41-50$ Years & 55 & 23.91 \\
\hline 5 & $>50$ Years & 49 & 21.30 \\
\hline & Total & $\mathbf{2 3 0}$ & $\mathbf{1 0 0}$
\end{tabular}

Source: primary data processed, 2020

Table 3. shows the characteristics of respondents based on the age of hotel guests in the Samosir area with an age distribution ranging from $25-30$ years, totaling 35 people or $15.22 \%$, $31-35$ years old totaling 41 people or $17.83 \%$, 36-40 years old totaling 50 people or $21.74 \%$, aged $41-50$ years amounted to 55 people or $23.91 \%$ and aged $>50$ years amounted to 49 people or $21.30 \%$.

Based on this data, it can be seen that tourists aged 25-30 years are the least tourists with only 35 people or $15.22 \%$ of the total. This shows that at that age range it is not routine and does not have high enthusiasm in traveling to Samosir.

Meanwhile, for the majority age range of tourists are tourists aged 41-50 years as many as 55 people or $23.91 \%$. This shows that the majority of tourists are at the age that requires natural tourism visits that can provide calm to the vulnerable at maturity.

\section{c. Characteristics of Respondents Based on Education Level}

The education level of respondents who visited Samosir Tourism can also be seen in the explanation of Table 4.2 below:

Table 4. Proportion of Respondents by Education Level

\begin{tabular}{cccc}
\hline No. & Level of education & Number of Respondents & Proportion (\%) \\
\hline 1 & Junior High & 29 & 12.61 \\
\hline 2 & SMA, SMK, STM & 59 & 25.65 \\
\hline 3 & D3 & 75 & 32.61 \\
\hline 4 & S1 & 48 & 20.87 \\
\hline 5 & S2 & 19 & 8.26 \\
\hline & total & $\mathbf{2 3 0}$ & $\mathbf{1 0 0}$ \\
\hline
\end{tabular}

Source: primary data processed, 2020

From Table 4.2, it can be seen that the characteristics of respondents based on the level of education of tourists visiting Samosir Tourism in junior high school education are 29 people or $12.61 \%$, high school education equals 59 people or $25.65 \%$, D3 education is 75 people or $32.61 \%, \mathrm{~S} 1$ education is 48 people or $20.87 \%$ of $\mathrm{S} 2$ education is 19 people or $8.26 \%$. From this data, it is known that the majority of the tourist education level is D3 with a total of 75 people or $32.61 \%$. Of course this shows that the level of education of hotel guests in the Samosir area is quite high. 


\section{d. Characteristics of Respondents by Work Unit}

Characteristics Hotel Guests in the Samosir Area by Hotel can be seen in Table 4.3 below:

Table 5. Respondents by Work Unit

\begin{tabular}{clcr}
\hline No. & \multicolumn{1}{c}{ Work unit } & Total & Proportion (\%) \\
\hline 1 & Head of Agency & 1 & 0.43 \\
\hline 2 & Secretary & 1 & 0.43 \\
\hline 3 & Head (Head of Field) & 4 & 1.74 \\
\hline 4 & Head of Subdivision (Head of Subdivision) & 3 & 1.30 \\
\hline 5 & Kasubbid (Head of Sub Division) & 12 & 5.22 \\
\hline 6 & Tourist Staff & 49 & 21.30 \\
\hline 7 & Members of the Task Force (Task Force) & 110 & 47.83 \\
\hline 8 & THL Officer (Independent Daily Personnel) & 50 & 21.74 \\
\hline & Total & $\mathbf{2 3 0}$ & $\mathbf{1 0 0}$ \\
\hline
\end{tabular}

Source: primary data processed, 2020

From the data obtained, respondents based on the BPBD Tourist work unit, it is known that the number of tourists in the BAAK education and evaluation sub-division work unit is 5 people $(4.81 \%)$, the BAAK Education Facilities Sub-Section is 5 people $(4.81 \%)$, the BAAK Cooperation Sub-Section is a number of 4 people (3.85\%), 5 people (4.81\%) BAAK Registration and Statistics Sub-Section, 7 BAAK Student Reasoning and Information SubSection (6.73\%), 8 BAUK Administration Sub-sections (7, 69\%), 7 people (6.73\%) of the Law and Administration of BAUK, 16 of the Equipment Sub-Section (15.38\%), 14 of the BAUK Administrative Personnel (13.46\%).

Furthermore, in the Academic Personnel Sub-Section a total of 8 people (7.69\%), the BAUK Routine Budget and Development Sub-Section 4 people (3.85\%), the Community Fund Sub-Section a total of 6 people (5.77\%), the BAUK Monitoring and Evaluation Sub-Section a number of 4 people (3.85\%), Academic Planning Sub-Section 2 people (1.92\%), Physical Planning Sub-Section 3 people (2.88\%), BAPSI Data Sub-Section 3 people (2.88\%), Services Sub-Section BAPSI information about 3 people $(2.88 \%)$.

The highest number of tourists was in the BAUK Equipment Sub-Section, as many as 16 people or $15.38 \%$. In the Equipment Sub-Section there is a buildup of tourists because in this subsection it takes a lot of technical personnel in the process of completing tasks such as building maintenance, as well as inventorying assets, facilities and infrastructure.

\subsection{Data analysis}

a. Research Descriptive Statistics

Descriptive statistics in this study summarize and provide an overall picture of the respondent's answers to each item of the statement used in measuring each research variable. Each item of the statement is measured using five answer categories that correspond to the agreement of the respondent on the given statement.

The variables in this study are the analysis of the position, experience, performance and performance of hotel guests in the Samosir area. The research descriptive statistics only aim to explain the answers of the research respondents and not to be generalized. The descriptive statistics of the study are tabulated based on the answers of all respondents to each item of the statement in the questionnaire and a summary of the answers is obtained which is then categorized in the conclusion group based on the average value (mean) of the respondents' answers. The grouping is divided as in Table 5 below: 
Table 6. Categorizing the Average Value of Respondents' Answers

\begin{tabular}{ccll}
\hline $\begin{array}{c}\text { Average value } \\
\text { (Mean) }\end{array}$ & Category & \multicolumn{1}{c}{$\begin{array}{c}\text { Conclusion } \\
\text { Answer }\end{array}$} & \multicolumn{1}{c}{$\begin{array}{c}\text { Variable } \\
\text { Conclusion }\end{array}$} \\
\hline $1.00-1.80$ & E & Strongly Disagree & Very bad \\
\hline $1.81-2.60$ & D & Disagree & Bad \\
\hline $2.61-3.40$ & C & Disagree less & Enough \\
\hline $3.41-4.20$ & B & Agree & Good \\
\hline $4.21-5.00$ & A & Strongly agree & Very good \\
\hline
\end{tabular}

Based on the average frequency of respondents' answers in Table 6, it can be seen that there are 3 indicators that measure Reliability (RL) where the average respondent's answer to the indicator Reliabilityis both in the range 3.41 - 4.20. On variablesResponsiveness (RV) has the average respondent's answer to the indicator Responsiveness is quite good in the range 2.61 - 3.40. On variablesAssurance (US) has the average respondent's answer to the indicator Assurance is both in the range 3.41 - 4.20. On variablesEmpathy (EM) has an average respondent's answer to the indicator Empathy is both in the range 3.41 - 4.20. On variablesTangibles (TS) has the average respondent's answer to the indicator Tangiblesis both in the range 3.41 - 4.20. On variablesCustomer Sutisfaction (CS) has an average respondent's answer to the indicator Customer Sutisfaction is both in the range 3.41 - 4.20.

\section{b. SEM Analysis}

Hypothesis testing is carried out to determine whether the hypothesis proposed by the researcher is accepted or rejected. Hypothesis testing is done using structural equation modeling (SEM) analysis. Apart from being used to accept and reject a hypothesis, SEM is also used to determine the level of suitability of the model built by the researcher. The stages of testing using SEM in this study are:

\section{1). Model Specifications}

In this study there are 11 observed variables with 2 latent variables with the overall model specifications shown as in Figure 3.3. There are 11 data from the observed variables, all of which are treated as continuous data. The analysis was performed using LISREL 8.8 software with a data file system as data input (.dsf) after forming the data in the form of an asymptotic covariance matrix.

The model in this study is a mixed model that combines the confirmatory factor analysis (CFA) model and the structural regression (SR) model. The CFA model forms two measurement models from the latent variables of job analysis (PR), work experience (PL) and performance (KK). The SR model is formed from two latent variables which are combined in the CFA model to form a mixed model.

\section{2). Model Fit Test}

Model fit test is conducted to determine the fit of the model. The model fit test is carried out through three stages including the fit test of the whole model, the fit test of the measurement model and the fit test of the structural model. The fit test of the whole model is assessed based on the measures contained in the goodness of index (GOFI) and the fit test of the measurement model is assessed based on the value of the validity of the observed variables and the reliability of the latent variables in the model. Meanwhile, the fit test of the structural model is measured based on the t-value of the loading factor.

This test is carried out using the Lisrel 8.8 software so as to produce the output as shown in the following figure: 


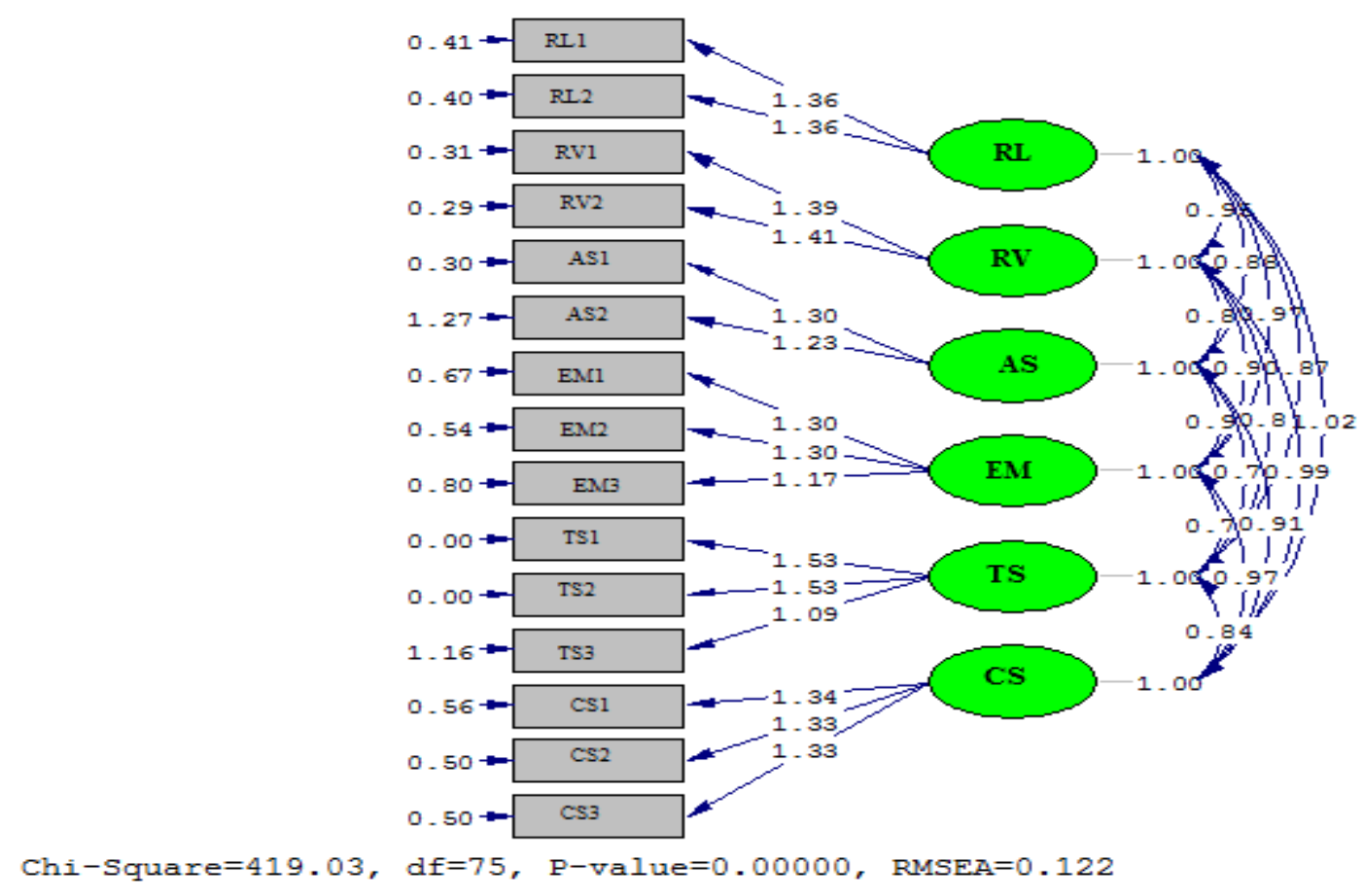

Figure 2. Basic Model-Estimates Path Diagram

The combination between Basic model estimates is a complete model display with nonstandardized estimation results. Figure 4.8 shows that the degrees of freedom of the model are $75(\mathrm{df}=75)$. The resulting santora-bentler scale value is 419.03 with a $\mathrm{p}$-value less than 0.05 (p-value: 0.000).

\section{3). Validity and Reliability Analysis}

Evaluation of the validity of the measurement model is considered good if it meets the criteria for a t-value $>1.96$ and the standardized loading factor is 0.30 .

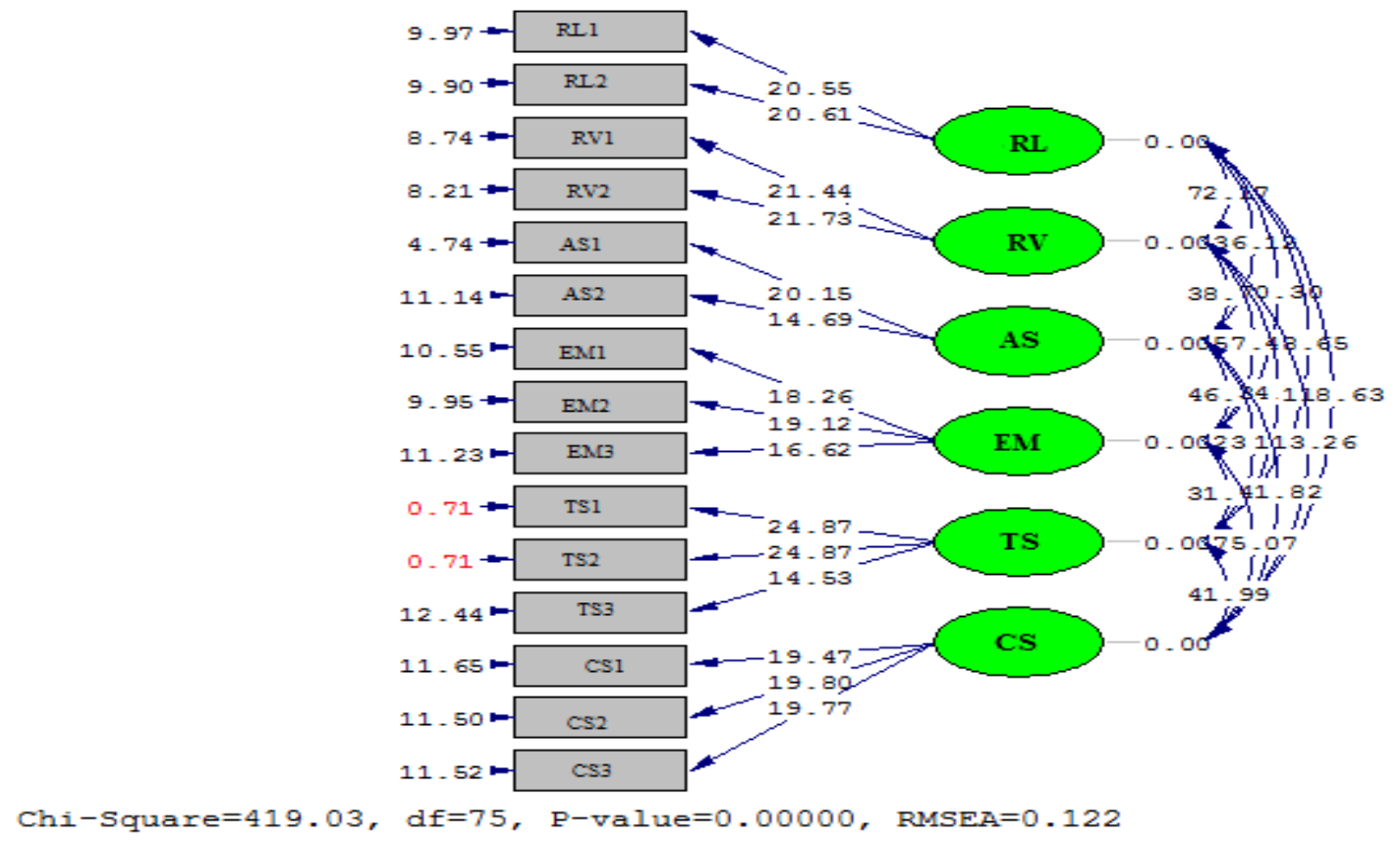

Figure 3. Loading factor 
Figure 3 shows that the t-value of the observed variable factor load>1.96, so it can be concluded that the factor loading contained in the model is significant or not equal to zero. The SLF value of all observed variables was $<0.05$. Based on the results above, it can be concluded that the validity of all observed variables for the latent variables is good.

Reliability of the Measurement Model Hair et.al (1998) states that a construct has good reliability, if it meets the Contruct Reliability (CR) value of 0.70 and the value of variance Extracted (VE) is 0.5065 .

Table 7. Reliability Value

\begin{tabular}{|c|c|c|c|}
\hline Latent Variable & CR & VE & Reliability \\
\hline RL & 0.79 & 0.55 & Good \\
\hline RV & 0.81 & 0.58 & Good \\
\hline US & 0.80 & 0.56 & Good \\
\hline EM & 0.79 & 0.55 & Good \\
\hline TS & 0.81 & 0.58 & Good \\
\hline CS & 0.80 & 0.56 & Good \\
\hline
\end{tabular}

$\mathrm{CR}$ and VE values were obtained based on the loading standard values and the error variance of the observed variables. Based on the table above, it shows that the value of construct reliability (CR) and variance extracted (VE) meets the criteria except that the TS of the latent variables RL, RV, AS, EM and CS are above the specified criteria (0.41 0.50). So it can be concluded that the latent variable reliability is good.

\section{4). Structural Model Fit}

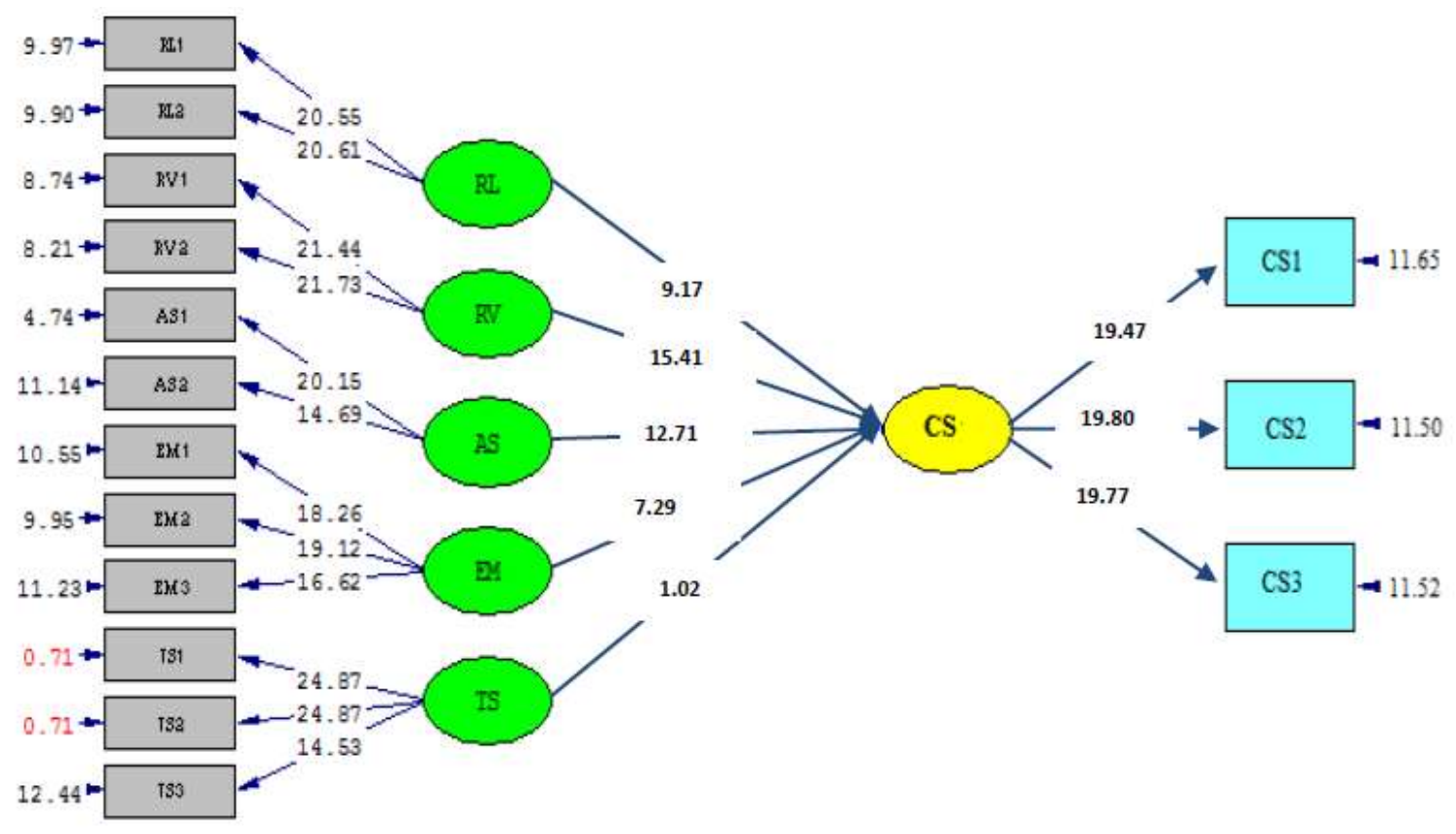

Chi-Square $=419.03, \mathrm{df}=75, \mathrm{P}$-value $=0.00000$, RMSEA $=0.122$

Figure 4. Path diagram of structural model-t values

The structural model-t value combination path diagram shows the relationship between latent variables. The structural model describes the causal relationship to its latent variables. Latent variables in structural models are usually used as hypotheses in a study. Figure 4. shows 
the structural error value of the latent Tangibles (TL) variable of 0.71 which is shown in red. This means that the structural error is insignificant or equal to zero. Meanwhile, the t-values for other variables are set by default by LISREL so that they show a significant number. After the fit test is carried out, the coefficients on the structural model can be seen in the table.

Table 8. Structural Model Analysis

\begin{tabular}{|l|c|c|c|c|}
\hline Path & Estimate & Value of $\mathrm{t}$ & Hypothesis & Conclusion \\
\hline RL CS & 0.11 & 9.17 & Be accepted & Take effect \\
\hline RV CS & 0.53 & 15.41 & Be accepted & Take effect \\
\hline AS CS & & 12.71 & Be accepted & Take effect \\
\hline EM CS & & 7.29 & Be accepted & Take effect \\
\hline TS CS & 0.11 & 1.02 & Rejected & No effect \\
\hline
\end{tabular}

From table 4.8, it shows that the estimation results of the effect of the latent variable RL on CS are 0.11 based on the value of the standardized loading factor. The t-value shown in the structural model image is 9.17 or meets the expected loading factor criteria (2.35). This means that the t-value is not equal to 0 (zero) so that it can be concluded that $\mathrm{H} 1$ is accepted or that the structural model is significant.

\section{Conclussion}

The estimation result of the effect of the latent variable RV on CS is 0.11 based on the value of the standardized loading factor. The t-value shown in the structural model image is 15.41 or meets the expected factor loading criteria (2.35). This means that the t-value is not equal to 0 (zero) so that it can be concluded that $\mathrm{H} 1$ is accepted or that the structural model is significant.

The estimation result of the effect of AS latent variable on CS is 0.11 based on the standardized loading factor value. The t-value shown in the structural model image is 12.71 or meets the expected factor loading criteria (2.35). This means that the t-value is not equal to 0 (zero) so that it can be concluded that $\mathrm{H} 1$ is accepted or that the structural model is significant.

The estimation result of the effect of the latent variable EM on CS is 0.11 based on the value of the standardized loading factor. The t-value shown in the structural model image is 7.29 or meets the expected loading factor criteria (2.35). This means that the t-value is not equal to 0 (zero) so that it can be concluded that $\mathrm{H} 1$ is accepted or that the structural model is significant.

The estimation result of the effect of the latent variable TS on CS is 0.11 based on the value of the standardized loading factor. The t-value shown in the structural model image is 1.02 or does not meet the expected factor loading criteria (2.35). This means that the t-value is equal to 0 (zero) so that it can be concluded that $\mathrm{H} 1$ is rejected or the structural model is insignificant. 


\section{Suggestions}

By looking at the limitations stated above, the authors realize that no research is perfect. For this reason, constructive suggestions for this research will be put forward by the author as follows:

1. Hospitality Industry Management should be able to improve the quality of services provided, for example by conducting training for employees to be better at serving, providing easier and faster transaction facilities, and creating a more attractive and comfortable outlet atmosphere for tourists to create maximum tourist satisfaction and can increase sales.

2. Hospitality Industry Management must be able to optimize service factors such as reliability, responsiveness, assurance, empathy and tangibility that affect tourist satisfaction in order to create maximum tourist satisfaction.

3. Hospitality Industry Management must be able to improve service factors in terms of reliability and assurance because it is proven that it has not been able to affect tourist satisfaction.

4. Further research is expected to add other variables apart from service factors, for example from other factors such as brand image, price, facilities and so on which can affect tourist satisfaction.

\section{References}

Agus Suryana, (2007), Customer Service : Kiat Melayani Wisatawan Bebas Komplain, Jakarta : Khilina Pustaka

Amin, M et al. (2019). Marketing Communication Strategy To Improve Tourism Potential. Budapest International Research and Critics Institute-Journal (BIRCI-Journal). P. 160-166.

Ariyanti, Haruman, Ridwansyah dan Andre (2009), Pengaruh Kualitas Pelayanan Terhadap Kepuasan Mahasiswa Universitas Widyatama. Jurnal Manajemen Pemasaran.

Ariyani dan Rosinta (2010), Pengaruh Kualitas Layanan terhadap Kepuasan Wisatawan dalam Membentuk Loyalitas Wisatawan. Jurnal Manajemen Pemasaran.

Basu Swatha, DH. (2005). Azas-Azas Pemasaran. Yagyakarta: Liberty

Budi W. Soetjipto. (2002). Service Quality: Alternatif Pendekatan dan Berbagai Persoalan di Indonesia, Usahawan No. 01 Th. XXVI Januari.

Fandy Tjiptono dan Anastasia Diana. (2001). Penerapan Sistem Kualitas dalam Industri Jasa Berdasarkan Konsep Total Service quality. Jakarta; Manajemen dan Usahawan LMFE UI

Fandy Tjiptono. (2002). Manajemen Jasa. Edisi II, Yogyakarta: Andi Offset

J. Supranto, M.A. APU (2010). Perilaku Wisatawan \& Strategi Pemasaran Untuk Meningkatkan Persaingan Bisnis. Jakarta : Mitra Wacana Media

Kotler, Philip (2005). Manajemen Pemasaran, Analisis, Perencanaan dan Pengendalian. Jakarta. Terjemahan Ellen Gunawan. Edisi Kelima. Jilid I. Erlangga.

Lupiyoadi, Rambat dan Hamdani, A. (2001). Manajemen Pemasaran Jasa. Edisi Kedua. Jakarta: Salemba Empat.

Nurlina, (2020). Tourism Development in Langsa, Indonesia: An Overview of Tourist Attractions and Accommodation. Budapest International Research and Critics InstituteJournal (BIRCI-Journal). P.923-931

Rustika Atmawati (2007), Analisis pengaruh kualitas pelayanan terhadap kepuasan wisatawan pada matahari departemen stor di Solo. Jurnal Manajemen Pemasaran

Sugiyono. (2007). Metode Penelitian Bisnis. Bandung: Alfabeta.

Suharto Abdul Majid (2009). Customer Service Dalam Bisnis Jasa Transportasi Jakarta : PT. Raja Grafindo Persada 